\title{
Prenatal screening for HIV in Nova Scotia: Survey of postpartum women and audit of current prenatal screening practices
}

\author{
Mark Downing $\mathrm{BSc}^{1}$, Laura Youden $\mathrm{BSc}^{1}$, Beth A Halperin $\mathrm{MN}^{2}{ }^{2} 6$, \\ Heather Scott MD ${ }^{3,6}$, Bruce Smith $\mathrm{PhD}^{4}$, Scott A Halperin $\mathrm{MD}^{2,5,6}$
}

M Downing, L Youden, BA Halperin, H Scott, B Smith, SA Halperin. Prenatal screening for HIV in Nova Scotia: Survey of postpartum women and audit of current prenatal screening practices. Can J Infect Dis Med Microbiol 2006;17(4):224-228.

BACKGROUND: Current guidelines for screening for HIV infections in Nova Scotia recommend an opt-in approach in which patients are counselled and consent to testing. The objectives of the present study were to measure adherence to these recommendations, to explore women's knowledge, attitudes, beliefs and behaviours concerning HIV screening, and to compare these results with prenatal screening practices for rubella, hepatitis B and group B streptococcus. METHODS: All women who gave birth consecutively during a sevenweek period were recruited. Study participants were interviewed to determine their knowledge, attitudes and beliefs concerning prenatal screening. Hospital and laboratory records were reviewed for information concerning prenatal screening and perinatal treatment to audit screening practices.

RESULTS: A total of 279 patients were enrolled in the study, representing $58 \%$ of those eligible. The HIV screening rate was $72 \%$, compared with $95 \%$ for rubella, $89 \%$ for hepatitis B and $24 \%$ for group B streptococcus. Of the participants tested for HIV, $80 \%$ were aware of being tested. Of all the study participants, $17 \%$ indicated having received pretest counselling about $\mathrm{HIV}, 56 \%$ volunteered to be tested for HIV, $78 \%$ received the test results, and $3.8 \%$ received post-test counselling. More participants preferred an opt-out approach to HIV screening $(50 \%)$, where testing is routinely performed on everyone, rather than the opt-in approach (43\%). Participants displayed a similar preference for screening for the other infections.

INTERPRETATION: HIV prenatal testing rates in Nova Scotia are comparable with those of other provinces that recommend an opt-in approach, but are lower than testing rates for opt-out programs. Most study participants were not screened using the recommended opt-in approach.

Key Words: HIV antibodies; Mass screening; Pregnancy; Prenatal screening; Survey

\section{Le dépistage prénatal du VIH en Nouvelle- Écosse : Enquête auprès des femmes postpartum et vérification des pratiques courantes de dépistage prénatal}

\begin{abstract}
HISTORIQUE : D'après les lignes directrices courantes pour le dépistage des infections à VIH en Nouvelle-Écosse, il faut adopter une démarche volontaire, selon laquelle les patients sont conseillés et consentent à subir un test. La présente étude visait à mesurer le respect de ces recommandations, à explorer les connaissances, les attitudes, les croyances et les comportements des femmes au sujet du dépistage du VIH et à comparer ces résultats avec les pratiques de dépistage prénatal de la rubéole, de l'hépatite B et du streptocoque de groupe B.

MÉTHODOLOGIE : Toutes les femmes qui avaient accouché consécutivement pendant une période de sept semaines ont été recrutées. Les participantes ont été interviewées afin de déterminer leurs connaissances, leurs attitudes et leurs croyances au sujet du dépistage prénatal. Les dossiers de l'hôpital et des laboratoires ont été analysées afin d'obtenir de l'information sur le dépistage prénatal et le traitement périnatal et de vérifier les pratiques de dépistage.

RÉSULTATS : Au total, 279 patientes ont participé à l'étude, représentant $58 \%$ des personnes admissibles. Le taux de dépistage du VIH était de $72 \%$, par rapport à $95 \%$ pour la rubéole, $89 \%$ pour l'hépatite B et $24 \%$ pour le streptocoque de groupe B. Parmi les participantes ayant subi le dépistage du VIH, 80 \% savaient qu'elles avaient été testées. De toutes les participantes à l'étude, $17 \%$ ont indiqué avoir reçu de l'information au sujet du VIH avant le test, $56 \%$ ont demandé de subir le test du VIH, $78 \%$ ont reçu les résultats du test et 3,8\% ont reçu des conseils après la remise des résultats. Plus de participantes préféraient une démarche sans consentement pour le dépistage du VIH (50\%), où le test est systématiquement exécuté sur toutes les femmes, qu'une démarche volontaire $(43 \%)$. Les participantes accordaient une préférence similaire au dépistage des autres infections.

INTERPRÉTATION : En Nouvelle-Écosse, le taux de dépistage prénatal du VIH est comparable à celui des autres provinces qui recommandent un programme systématique. La plupart des participantes à l'étude n'avaient pas subi le dépistage dans le cadre de la démarche volontaire recommandée.
\end{abstract}

\footnotetext{
${ }^{1}$ Faculty of Medicine; ${ }^{2}$ Department of Pediatrics; ${ }^{3}$ Department of Obstetrics and Gynecology; ${ }^{4}$ Department of Mathematics and Statistics;

${ }^{5}$ Department of Microbiology and Immunology, Dalhousie University; ${ }^{6}$ IWK Health Centre, Halifax, Nova Scotia

Correspondence and reprints: Dr Scott A Halperin, Canadian Center for Vaccinology, Dalhousie University, IWK Health Centre,

5850/5980 University Avenue, Halifax, Nova Scotia B3K 6R8. Telephone 902-470-8141, fax 902-470-7232,

e-mail Scott.Halperin@dal.ca

Received for publication March 16, 2006. Accepted June 19, 2006
} 
$\mathrm{H}$ uman immunodeficiency virus can be transmitted from a mother to her infant during pregnancy (1-3), during delivery (4) or through breastfeeding (5); the risk of transmission generally ranges from $15 \%$ to $30 \%(6-9)$. Antiretroviral therapy during pregnancy has been shown to be effective in reducing the rate of vertical transmission of HIV (10). There has been much debate surrounding HIV prenatal screening, as the benefits of treatment must be weighed against the dangers of disregarding patient autonomy (11).

The Reproductive Care Program of Nova Scotia recommends that an opt-in approach be used with all women during prenatal screening, whereby every woman receives HIV counselling, consents specifically to HIV testing, and is counselled after testing (12). Some jurisdictions (Newfoundland, Alberta and the Northwest Territories) use an opt-out approach, whereby all women are tested unless they specifically refuse testing (13).

The purpose of the present study was to audit the prenatal screening practices for HIV at the IWK Health Centre, the tertiary care hospital for obstetrics and pediatrics in Nova Scotia. We also compared these results with screening programs for other infections that use different approaches, namely, rubella, hepatitis B and group B streptococcus (GBS). Tests for rubella and hepatitis $B$ are both universal screening programs in Nova Scotia and are performed at the same time as HIV testing, using the same requisition form; therefore, these programs provide a useful basis for comparing the opt-in approach. Finally, we explored postpartum women's experiences, knowledge, attitudes and beliefs concerning screening for HIV and compared these results with those of the other screening programs.

\section{METHODS}

The present study was performed at the IWK Health Centre, which provides perinatal care for the Halifax Regional Municipality in Nova Scotia (population 380,000). The IWK Health Centre was responsible for $55 \%$ of live births in Nova Scotia in 2004 and therefore provides a good representation of perinatal care in Nova Scotia. All mothers who gave birth to a live infant at the IWK Health Centre during a seven-week period (July 12, 2004, to August 23, 2004) were offered enrollment in the study the day after delivery. Exclusion criteria included having an infant in the neonatal intensive care unit or not being able to speak English. Eligible women were given a letter of introduction explaining the nature and the purpose of the study. Consenting study participants were interviewed by one of two medical students using a survey specifically designed for the study. Interviews were conducted within $48 \mathrm{~h}$ of delivery. After completion of the survey, all participants were given information sheets regarding the infections discussed in the survey. The study was approved by the Research Ethics Boards of the IWK Health Centre and the Queen Elizabeth II Health Sciences Centre.

The survey consisted of 65 questions and was administered during a $15 \mathrm{~min}$ interview. Before study initiation, the survey was pilot-tested by two focus groups and subsequently modified. The first group, comprising four postpartum mothers one day after their delivery, evaluated the survey for clarity and ease of completion. The second group, comprising five infectious disease specialists, used a content validity index to evaluate the survey. Interviewers were specifically trained in interviewing techniques. Participants were questioned on a number of demographic variables, including age, education, ethnic origin, number of pregnancies and deliveries, attendance at prenatal classes, type of care provider and area of prenatal care. Study participants were asked whether they had undergone prenatal screening and counselling for hepatitis B, HIV, GBS and rubella. Questions were also asked about experiences with prenatal testing and attitudes toward screening protocols.

The IWK Health Centre laboratory database and health records were reviewed for laboratory results concerning prenatal testing. Acceptable screening tests included a rubella antibody titre performed any time during or before the pregnancy, hepatitis B surface antigen serology performed any time during or before pregnancy, HIV antibody serology performed any time during pregnancy, and GBS cultures from vaginal-rectal swabs taken at 35 to 37 weeks gestation. In addition, charts were examined for documentation of pretest counselling for HIV. Laboratory results from participants who had incomplete information after chart review were sought from a list of test results that were provided from the Queen Elizabeth II Health Sciences Centre, the only other hospital providing prenatal laboratory testing in the Halifax Regional Municipality. If participants indicated that they received all of their prenatal care in the Halifax Regional Municipality but a test result was not found at either of these two hospitals, then it was assumed the test was not performed. To identify tests that were performed outside of Halifax, family doctors were contacted to provide any remaining information.

Binomial point estimates and exact binomial confidence intervals were used to summarize proportions. Fisher's exact test, the Fisher-Freeman-Halton test or Monte Carlo estimates were used to compare demographic variables with survey questions and chart review results. Fisher's exact test was used to compare screening preferences across infection types. Results were considered significant at $\mathrm{P}<0.05$. A sample size of 271 was calculated to ensure a $95 \%$ CI half width of $5 \%$ for the point estimates.

\section{RESULTS}

Of 484 eligible women, 279 (58\%) consented to take part in the study. Seventy-six of the 205 nonparticipants were discharged from hospital before they could be approached for consent; the remaining 129 women declined to meet with the investigators. All 279 study participants completed interviews. After laboratory and health records were reviewed, and family physicians contacted, the following information remained missing: one participant had an unknown rubella immunity status; six participants had an unknown status for GBS testing; and one participant had an unknown status for hepatitis B surface antigen serology. Whether or not the prenatal care provider ordered HIV testing was determined for all participants.

Most participants received all of their prenatal care in the Halifax Regional Municipality (Table 1). Most participants were 25 to 34 years of age, had a postsecondary degree and were primiparous. A similar number of participants was followed by family doctors and obstetricians. Demographic characteristics were similar among those who received all their care in the Halifax Regional Municipality and all study participants.

The HIV testing rate was $72.0 \%$ (95\% CI 66.4 to 77.2 ). Rubella and hepatitis B testing levels (the two universal screening programs) were $95.0 \%$ (95\% CI 91.7 to 97.2 ) and 89.2\% (95\% CI 85.0 to 92.6), respectively. GBS testing levels were the lowest at $24.0 \%$ (95\% CI 19.1 to 29.5$)$. This was expected because both GBS testing and screening by risk 
TABLE 1

Demographic characteristics of the study population

\begin{tabular}{|c|c|c|}
\hline Characteristic & Category & $\begin{array}{l}\text { portion reporting, } \\
\%(95 \% \mathrm{Cl})\end{array}$ \\
\hline \multirow[t]{4}{*}{ Age, years } & Under 18 & $1.4(0.4-3.6)$ \\
\hline & $18-24$ & $17.6(13.3-22.5)$ \\
\hline & $25-34$ & $63.8(57.9-69.4)$ \\
\hline & $35-44$ & $17.2(13.0-22.2)$ \\
\hline \multirow[t]{5}{*}{ Education } & Less than high school & $7.2(4.4-10.9)$ \\
\hline & Completed high school & $15.0(11.1-19.8)$ \\
\hline & Some postsecondary & $18.3(13.9-23.3)$ \\
\hline & Completed postsecondary & $47.7(41.7-53.7)$ \\
\hline & Advanced degree & $11.8(8.3-16.2)$ \\
\hline \multirow[t]{4}{*}{ Number of pregnancies } & One & $42.7(36.8-48.7)$ \\
\hline & Two & $29.7(24.4-35.5)$ \\
\hline & Three & $14.3(10.4-19.0)$ \\
\hline & Four or more & $13.3(9.5-17.8)$ \\
\hline \multirow[t]{4}{*}{ Number of deliveries } & One & $52.3(46.3-58.8)$ \\
\hline & Two & $30.8(25.5-36.6)$ \\
\hline & Three & $12.5(8.9-17.0)$ \\
\hline & Four or more & $4.4(2.2-7.4)$ \\
\hline \multirow[t]{5}{*}{ Ethnic origin } & White & $90.3(86.2-93.5)$ \\
\hline & Black & $2.5(1.0-5.1)$ \\
\hline & Asian & $3.2(1.5-6.0)$ \\
\hline & First Nations & $1.4(0.4-3.6)$ \\
\hline & Other & $2.5(1.0-5.1)$ \\
\hline \multirow{2}{*}{$\begin{array}{l}\text { Attended prenatal classes } \\
\text { during the pregnancy }\end{array}$} & Yes & $41.6(35.7-47.6)$ \\
\hline & No & $58.4(52.4-64.3)$ \\
\hline \multirow{2}{*}{$\begin{array}{l}\text { Primary health care } \\
\text { provider (participants }\end{array}$} & Family physician & $55.9(49.9-61.8)$ \\
\hline & Obstetrician & $58.4(52.4-64.3)$ \\
\hline could choose more & Other & $0.7(0.1-2.6)$ \\
\hline than one option) & Don't know & $1.4(0.4-3.6)$ \\
\hline \multirow{2}{*}{$\begin{array}{l}\text { Location of prenatal care } \\
\text { (participants could }\end{array}$} & Halifax Regional Municipality & $92.5(88.7-95.3)$ \\
\hline & Mainland Nova Scotia & $9.7(6.5-13.8)$ \\
\hline choose more than & Cape Breton & $1.4(0.4-3.6)$ \\
\hline \multirow[t]{2}{*}{ one option) } & Outside of Nova Scotia & $6.5(3.9-10.0)$ \\
\hline & Outside of Canada & $1.8(0.6-4.1)$ \\
\hline
\end{tabular}

factor were acceptable practices at the time the study was undertaken.

The proportion of participants who were aware of being tested for HIV was $80.1 \%$ (95\% CI 73.9 to 85.4 ). Fewer participants were aware of being tested for hepatitis B $(39.0 \%$; $95 \%$ CI 32.9 to 45.3 ) and rubella $(50.6 \%$; $95 \%$ CI 44.4 to 56.7), which would be expected considering these tests are part of routine prenatal blood work. Participants were most aware of being tested for GBS (83.6\%; 95\% CI 71.2 to 92.2 ), which was also to be expected because this test is much more invasive and would have been done relatively close to delivery.

The proportion of study participants who indicated that they received pretest counselling for HIV testing was $17.4 \%$ (95\% CI 13.1 to 22.4) (Table 2). A similar proportion of patients underwent documented HIV counselling (17.9\%; 95\% CI 13.6 to 22.9). Of the participants who indicated that they were tested, only $56.3 \%$ (95\% CI 48.9 to 63.6) indicated that they had given specific consent to HIV testing. After
TABLE 2

Summary of responses to survey questions about experiences regarding prenatal HIV screening

\begin{tabular}{lc}
\hline Category & $\begin{array}{c}\text { Proportion reporting, } \\
\%(95 \% \mathrm{CI})\end{array}$ \\
\hline $\begin{array}{l}\text { Participants who indicated they received } \\
\text { pretest counselling }\end{array}$ & $17.4(13.1-22.4)$ \\
$\begin{array}{l}\text { Participants who had documented } \\
\text { pretest counselling }\end{array}$ & $17.9(13.6-22.9)$ \\
$\begin{array}{l}\text { Participants tested for HIV who indicated } \\
\text { that they gave consent to testing }\end{array}$ & $56.3(48.9-63.5)$ \\
$\begin{array}{l}\text { Participants tested for HIV who indicated } \\
\text { that they were given test results }\end{array}$ & $78.4(71.9-84.0)$ \\
Participants tested for HIV who indicated that \\
they were counselled after testing
\end{tabular}

HIV testing, $78.4 \%$ (95\% CI 71.9 to 84.0 ) of participants who were tested received their test results, and only $3.8 \%$ (95\% CI 1.6 to 7.7 ) who were tested received post-test counselling. Study participants who were not tested were asked to give reasons for not being tested. The majority indicated that they were not tested because they were not offered the test (62.1\%). Other reasons for not receiving HIV testing included having already been tested before the pregnancy $(24.1 \%)$ and not believing to be at risk for having an HIV infection $(5.2 \%)$.

Study participants were also asked about how they thought HIV prenatal screening should be performed. The options given were routine testing for everyone, offering the test to everyone, routine testing of high-risk individuals only, and offering the test to high-risk individuals only. Routine testing for everyone is referred to in the literature as the opt-out approach, whereas offering the test to everyone is referred to as the opt-in approach. One-half of the study participants chose the opt-out approach as their preferred method of screening, whereas $42.8 \%$ chose the opt-in approach. There were no significant differences between these preferences and the preferences for prenatal screening of rubella, hepatitis B and GBS. Participants who chose the opt-out approach also indicated whether they would want HIV counselling before testing. The majority $(76.3 \%)$ indicated that they would want HIV counselling, demonstrating that, overall, most participants would want HIV counselling regardless of whether the screening was opt-in or opt-out.

There were no differences in survey responses or HIV testing rates based on age, number of pregnancies or attendance at prenatal classes. All women who had less than a high school education were given their test results, whereas the women with higher levels of education less commonly received their test results $(61 \%$ to $80 \% ; \mathrm{P}=0.049)$. There were no significant differences based on whether the primary health care provider was a family physician or an obstetrician. Finally, results were compared between those who received all of their care in the Halifax Regional Municipality and those who received all of their care in rural Nova Scotia (mainland Nova Scotia and Cape Breton). The only significant difference was in the documentation of HIV pretest counselling: $17 \%$ of participants had documented HIV counselling in Halifax, whereas 29\% of participants had documented HIV counselling in rural Nova Scotia $(\mathrm{P}=0.0012)$. 


\section{DISCUSSION}

The present study found the prenatal testing rate for our group of participants to be $72 \%$. This is a significant improvement over the rate of $45 \%$ that was reported in 2000 at the same centre (14). A substantial proportion of women are still not receiving testing. The prenatal testing rate for HIV in Nova Scotia is comparable with that of other provinces that use an opt-in approach, but is lower than in provinces that use an opt-out approach. Ontario and British Columbia both use an opt-in approach and have reported testing rates of $72 \%$ and $76 \%$, respectively $(15,16)$. Alberta and Newfoundland have adopted an opt-out approach and have much higher testing rates, at $98 \%$ and $94 \%$, respectively $(17,18)$.

Our results also indicate that there are deficiencies in the HIV counselling process in Nova Scotia. Relatively few women received pretest and post-test counselling, a large number of study participants did not consent to the test, a significant number of women were not aware of being tested, and most women who were not tested were not offered the test. Mechanisms need to be put into place to ensure that women receive proper HIV counselling during pregnancy. Currently, resources are not available for physicians to do this routinely during prenatal appointments. Further exploration is required to determine whether physicians are willing and able to provide counselling if resources were available. Innovative methods for providing women with information regarding HIV testing must be developed to allow more women the opportunity to obtain HIV testing in a consensual fashion. This may include resources such as written information that patients may read before their appointment, or trained individuals who can provide counselling outside of prenatal visits.

Attitudes about HIV screening have been gradually shifting in favour of the opt-out approach, which produces higher testing frequencies. The low rates of counselling and consent to testing in the present study may indicate that some physicians are using an opt-out approach for HIV screening. The major concern with the opt-out approach is that the number of women who receive HIV counselling could decrease. There could be grave implications for a woman who tests positive for HIV, including, for example, depression, social isolation and discrimination. These problems could escalate if appropriate pretest and post-test counselling is not undertaken.

There are several limitations to the present study. Because the acceptance rate was $58 \%$ and demographic information was not obtainable from patients not enrolled in the study, the results may not be generalizable to the entire population in Halifax or Nova Scotia. For instance, $16 \%$ of eligible women were discharged from hospital before they could be approached by the investigators; this group could have represented those with the lowest risks at childbirth. The participants who were enrolled primarily represented an urban population with high levels of postsecondary education. HIV screening in more rural areas may present a different picture; we did find a higher rate of documentation of counselling in rural Nova Scotia than in urban Nova Scotia. Finally, no participants in the study tested positive for HIV. There has been only one study (19) estimating the prevalence of HIV infection during pregnancy; only one case was identified among almost 15,000 pregnant women. Therefore, it was expected that we would not have any subjects in our study with HIVpositive serology. Nonetheless, HIV-positive individuals may have different attitudes toward prenatal HIV screening compared with the subjects in the present study.

Another limitation of the study is that participants were asked to recall events that happened early in the pregnancy; hence, there may be a significant element of recall bias in their survey responses. Undoubtedly, women do not remember all of the details of their prenatal care visits; however, counselling in the present study was considered to be any form of discussion about HIV testing. Guidelines for counselling for HIV testing involve providing information about the infection, risk factors, testing options, confidentiality and the implications of results (20). If participants could not recall the counselling they received about HIV or whether they were tested, then the counselling may have been inadequate.

In conclusion, the findings from our study indicate that HIV testing rates are relatively low during pregnancy, and that HIV counselling is often inadequate. Testing rates may be improved by an opt-out approach, as only those provinces with such an approach have been able to reach rates greater than $90 \%$. If an opt-out approach were to be adopted, a mechanism would need to be established to ensure that HIV counselling takes place before testing. HIV counselling is an ethical obligation that prepares the patient for the serious consequences that could result from a positive test.

ACKNOWLEDGEMENTS: The authors thank the staff at the Clinical Trials Research Center, Darlene Baxendale for her contribution to the research ethics proposal, and Donna MacKinnonCameron for her contribution to the data analysis. The authors also thank Dr Kevin Forward for providing help from the Queen Elizabeth II Health Sciences Centre Laboratory (Halifax, Nova Scotia). This study was supported by the Dalhousie Undergraduate Medical Student Summer Research Program and the IWK Health Centre.

\section{REFERENCES}

1. Lapointe N, Michaud J, Pekovic D, Chausseau JP, Dupuy JM. Transplacental transmission of HTLV-III virus. N Engl J Med 1985;312:1325-6.

2. di Maria H, Courpotin C, Rouzioux C, et al. Transplacental transmission of human immunodeficiency virus. Lancet 1986;2:215-6.

3. Sprecher S, Soumenkoff G, Puissant F, Degueldre M. Vertical transmission of HIV in 15-week fetus. Lancet 1986;2:288-9.

4. Ehrnst A, Lindgren S, Dictor M, et al. HIV in pregnant women and their offspring: Evidence for late transmission. Lancet 1991;338:203-7.

5. Hira SK, Mangrola UG, Mwale C, et al. Apparent vertical transmission of human immunodeficiency virus type 1 by breastfeeding in Zambia. J Pediatr 1990;117:421-4.

6. Gabiano C, Tovo PA, de Martino M, et al. Mother-to-child transmission of human immunodeficiency virus type 1 : Risk of infection and correlates of transmission. Pediatrics 1992;90:369-74.

7. Blanche S, Rouzioux C, Moscato ML, et al. A prospective study of infants born to women seropositive for human immunodeficiency virus type 1 . HIV Infection in Newborns French Collaborative Study Group. N Engl J Med 1989;320:1643-8.

8. Goedert JJ, Mendez H, Drummond JE, et al. Mother-to-infant transmission of human immunodeficiency virus type 1: Association with prematurity or low anti-gp120. Lancet 1989;2:1351-4.

9. Risk factors for mother-to-child transmission of HIV-1. European Collaborative Study. Lancet 1992;339:1007-12.

10. Connor EM, Sperling RS, Gelber R, et al. Reduction of maternal infant transmission of human immunodeficiency virus type 1 with zidovudine treatment. Pediatric AIDS Clinical Trials Group Protocol 076 Study Group. N Engl J Med 1994;331:1173-80. 
11. Walmsley S. Opt in or opt out: What is optimal for prenatal screening for HIV infection? CMAJ 2003;168:707-8.

12. Reproductive Care Program of Nova Scotia. Guidelines for antenatal laboratory screening and testing and HIV counseling guidelines. $<$ http://rcp.nshealth.ca/files/Antenatal.pdf $>$ (Version current at July 20, 2006).

13. Infectious Diseases and Immunization Committee, Canadian Paediatric Society (CPS). Testing for Human Immunodeficiency Virus Type 1 (HIV-1) infection in pregnancy. Paediatr Child Health. 2001;6:685-9.

14. Côté SJ, Halperin SA. Compliance with recommendations for routine HIV screening during pregnancy in Halifax. Paediatr Child Health 2002;7:81-4.

15. Gruslin A, Salvador A, Dekker M, Menard-de Varennes D, Eason E. Prenatal HIV screening in a tertiary care centre. Can J Public Health 2001;92:255-8.
16. Patrick DM, Money DM, Forbes J, et al. Routine prenatal screening for HIV in a low-prevalence setting. CMAJ 1998;159:942-7.

17. Jayaraman GC, Preiksaitis JK, Larke B. Mandatory reporting of HIV infection and opt-out prenatal screening for HIV infection: Effect on testing rates. CMAJ 2003;168:679-82.

18. Centers for Disease Control and Prevention (CDC). HIV testing among pregnant women - United States and Canada, 1998-2001. MMWR Morb Mortal Wkly Rep 2002;51:1013-6.

19. Johnston BL, Haase DA, Armson BA, Lee SH, Manley K, Hazell P. Seroprevalence of HIV infection in childbearing women in Nova Scotia. Can J Public Health 1997;88:27-31.

20. Samson L, King S. Evidence-based guidelines for universal counselling and offering of HIV testing in pregnancy in Canada. CMAJ 1998;158:1449-57. (Erratum in 1998;159:22). 


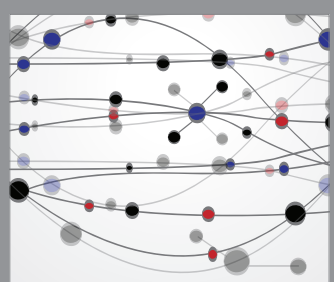

The Scientific World Journal
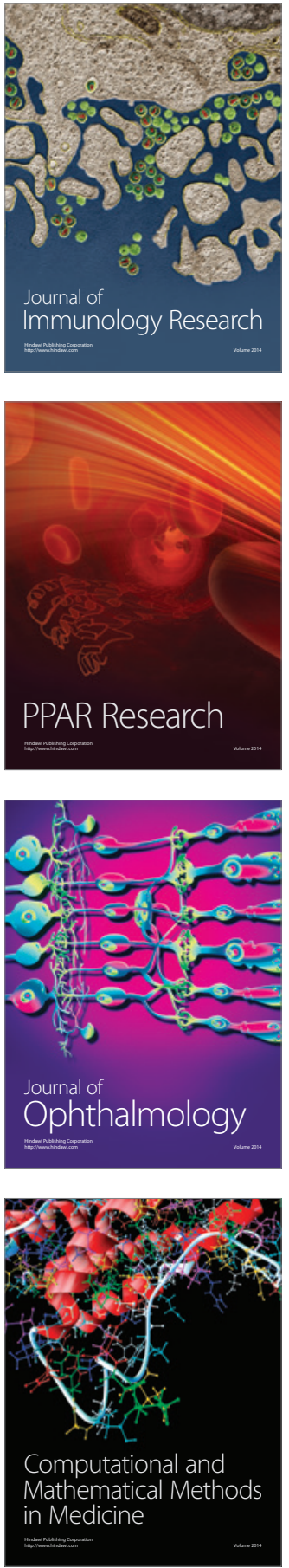

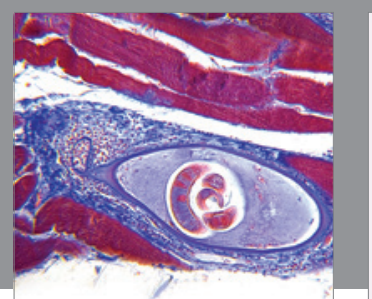

Gastroenterology Research and Practice

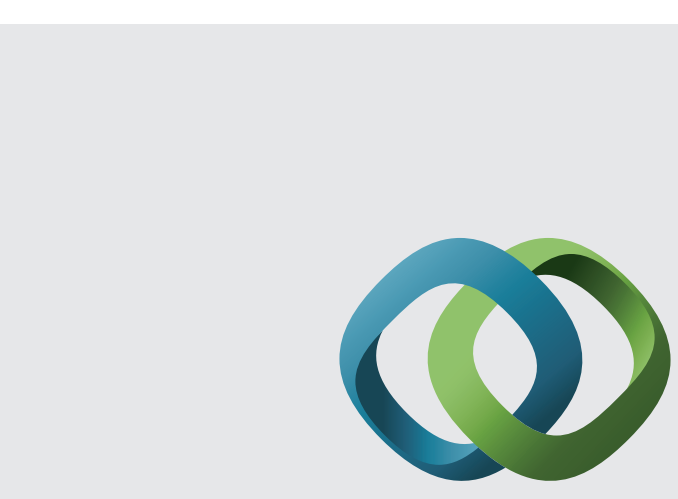

\section{Hindawi}

Submit your manuscripts at

http://www.hindawi.com
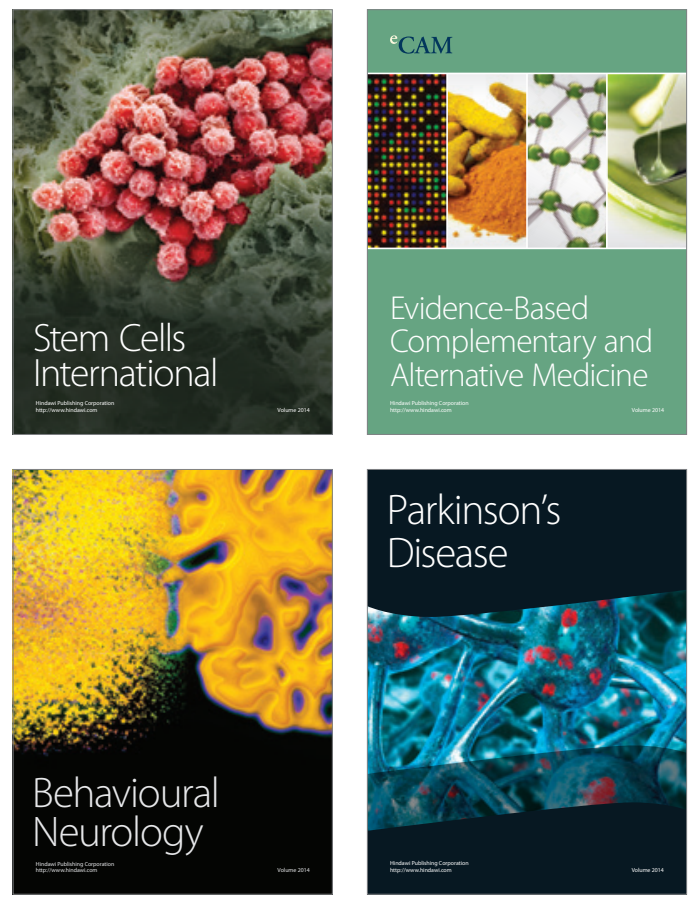
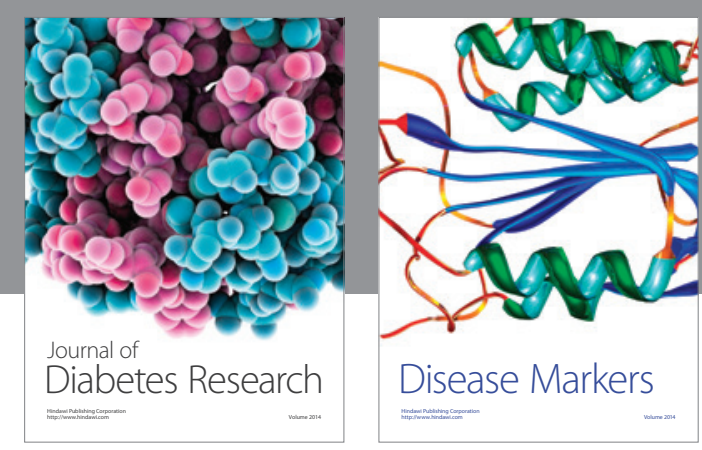

Disease Markers
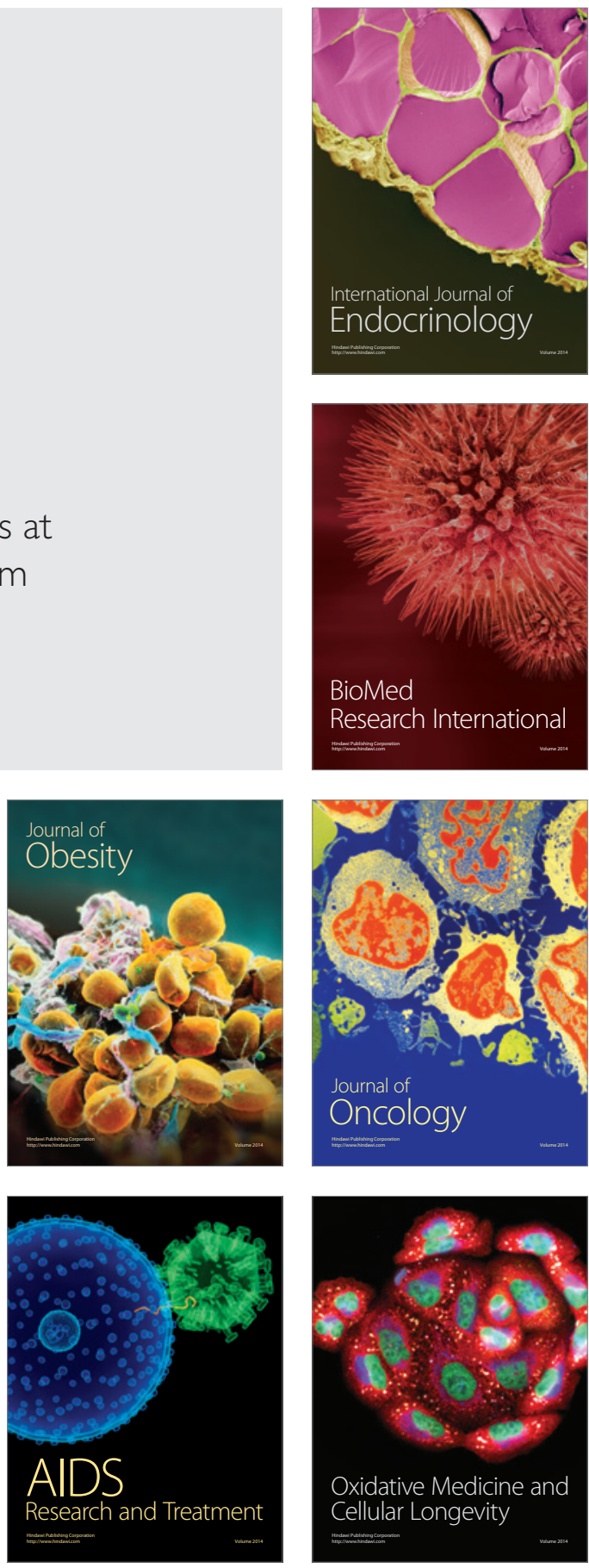